\title{
PRISPEVKI ZA ANALIZO IZZIVOV IN PRIHODNJEGA RAZVOJA TER OBSEGA VOJSKE V SLOVENIJI
}

\section{CONTRIBUTIONS TO THE ANALYSIS OF CHALLENGES, FUTURE DEVELOPMENT AND SCOPE OF ARMED FORCES IN SLOVENIA}

Povzetek V prispevku predstavljam razmišljanja in ugotovitve iz preučevanja tranzicije in transformacije Slovenske vojske glede na prihodnje izzive in razvoj. Konec leta 2016 je vlada sprejele sklepe Strateškega pregleda obrambe, ob tem pa so bile izvedene še druge analize in študije. Strokovna javnost je svoj pogled na vzdržljivosti obrambnovojaškega in varnostnega sistema ter vlogo rezerve pri tem predstavila v posebnem zborniku in tako prispevala k analizi stanja in pogleda na prihodnji razvoj. Leta 2017 so bili sprejeti zavezniški cilji zmogljivosti za Republiko Slovenijo in njeno vojsko. Poleg tega v Sloveniji že drugo leto poteka posodabljanje normativne ureditve. Prav tako poteka intenzivno dopolnjevanje strateških in razvojnih dokumentov obrambnega resorja, vključno s študijami in razpravami ter programiranjem prihodnje strukture in obsega Slovenske vojske. Vsi ti procesi so usmerjeni v nadaljnje preoblikovanje, vendar v trenutnih okvirih in brez sistemskih sprememb. Pri tem je pojav transformacije vojske skoraj v celoti izginil iz razprav o prihodnjih izzivih. V politični in strokovni javnosti je zaslediti tudi razmišljanja o nujnosti nove vizije in razvojni poti, z bolj radikalnim spreminjanjem in posegi $\mathrm{v}$ sistemske, normativne in tudi strukturne rešitve. Čeprav smo v Sloveniji sredi procesov projektiranja in programiranja ter normativnega urejanja obrambno-vojaškega sistema, menim, da je potrebna ponovna oziroma vmesna analiza. Opozarjam na nujnost premisleka o še vedno odprtih vprašanjih in dodajam poglede na to, kateri so ti izzivi.

Ključne Analiza izzivov in prihodnjega razvoja, vizija sprememb, obseg in struktura besede Slovenske vojske, prě̌ivetje, tranzicija, transformacija.

Abstract In the paper, I present my thoughts and findings from the study of the transition and transformation of the Slovenian Armed Forces in the light of future challenges and development. At the end of 2016, the government adopted the decisions of the Strategic Defence Review, while other analyses and studies have also been carried out. The professional public presented its view on the sustainability of the defence, 
military and security system and the role of the reserve therein in a special journal, thus contributing to the analysis of the situation and the view on the future development. In 2017, NATO Capability Targets for the Republic of Slovenia and its armed forces were adopted. In addition, the modernization of the normative regulation in Slovenia has been underway for the second year. Also, intensive complementing of strategic and developmental documents of the defence sector is in progress, including studies and debates, as well as the programming of the future structure and scope of the Slovenian Armed Forces. All these processes are oriented towards further transformation; however, within the current scope and without systemic changes. With this in mind, the phenomenon of transformation of armed forces has disappeared almost completely from the discussions on future challenges. In the political and professional public, there are also reflections on the urgent need for a new vision and development path, with more radical changes to and interventions in the systemic, normative and structural solutions. Although Slovenia finds itself in the midst of the processes of designing and programming as well as normatively regulating its defence and military system, I believe that a re-analysis or an interim analysis is needed. I want to draw attention to the urgency of reflection on the still open questions and to add my view on what these challenges might be.

\section{Key words Analysis of the challenges and future development, vision of changes, scope and structure of the Slovenian Armed Forces, survival, transition, transformation.}

Uvod Ta prispevek temelji na vsebini knjige, ki sem jo napisal o razvoju Slovenske vojske in njeni poti med tranzicijo in transformacijo (Šteiner, 2015). Ker je raziskava za knjigo zajela obdobje do konca leta 2014, so dodane ocene in primerjave o obravnavani tematiki za čas po letu 2014. V tej publikaciji so to problematiko v tem obdobju obravnavali tudi nekateri drugi avtorji ${ }^{1}$. Čeprav smo v Sloveniji sredi procesov projektiranja in programiranja ter normativnega urejanja obrambno-vojaškega sistema, menim, da je potrebna ponovna oziroma vmesna analiza. Namen prispevka je predstaviti trditve in dejstva o aktualnih vprašanjih in izzivih pri pripravljenih rešitvah, pa tudi o tistih, ki se jih je treba še lotiti. Vojaški voditelji in politične avtoritete, pristojne za upravljanje obrambno-vojaškega sistema, ter subjekti parlamentarnega nadzora nad tem področjem se namreč ne bi smeli zadovoljiti le s parcialnimi odgovori na zamišljene ali pripravljene rešitve, temveč iskati predvsem celovita stališča o tem, pa tudi odgovore o viziji in strategiji sprememb.

Mogoče bo kdo v zapisanem našel izhodišča za v politični javnosti že večkrat omenjeno belo knjigo prihodnje preobrazbe slovenskega obrambno-vojaškega in zaščitno-reševalnega sistema, kar pa ni temeljni namen prispevka. Na napakah se je modro učiti, čeprav bi se jim v primerih, ko se dogajajo na živih strukturah in ljudeh, morali izogibati, nikakor pa si zatiskati oči ali se izmikati spremembam in prizadevanjem za izboljšanje.

1 Glej: Kotnik, 2015, Young, 2016 in Žurga, 2016. 


\section{STRATEŠKI PREGLED OBRAMBE IN RAZPRAVE O IZZIVIH IN PRIHODNJEM RAZVOJU TER OBSEGU VOJSKE V SLOVENIJI}

$\mathrm{V}$ nadaljevanju predstavljam primere, $\mathrm{s}$ katerimi smo $\mathrm{v}$ Sloveniji poskušali sistematično in prek različnih pristopov priti do objektivnega stanja in pogledov nanj v obrambno-vojaškem sistemu ter posledično do ustreznih razvojnih rešitev. $\mathrm{Na}$ normativnem področju je skladno z vladno koalicijsko pogodbo bila v ospredju priprava sprememb obrambne zakonodaje, ki je v času pisanja tega prispevka $\mathrm{v}$ parlamentarni proceduri. Hkrati s snovanjem sprememb Zakona o obrambi in Zakona o službi v Slovenski vojski je potekal strateški pregled obrambe (SPO), zatem pa so bile izvedene še druge analize in študije. Temu so sledile dejavnosti na področju obrambnega načrtovanja pri spreminjanju strateških dokumentov in razvojnih načrtov. Strokovna javnost je svoj pogled na stanje in prihodnji razvoj obrambnovojaškega in varnostnega sistema izrazila na nacionalnem posvetu v Državnem svetu in predstavila v Zborniku o vlogi rezerve pri zagotavljanju vzdržljivosti obrambnovarnostnih sistemov Slovenije (Šteiner, 2016). Leta 2017 so v zavezništvu sprejeli cilje zmogljivosti za Republiko Slovenijo in njeno vojsko. V Slovenski vojski so izvedene strukturne spremembe s ponovno vzpostavitvijo Poveljstva sil kot operativne ravni poveljevanja. Generalštab pripravlja študije in načrte za bodočo organizacijo in obseg Slovenske vojske. V prispevku ne omenjam vsega, kar je oziroma ni potekalo $\mathrm{v}$ obrambnem resorju oziroma $\mathrm{v}$ vojski in je povezano s konsolidacijo financiranja, popolnjevanja ali nadaljevanja funkcionalne profesionalizacije vojske.

\subsection{Strateški pregled obrambe 2016}

Priprava $^{2}$ in izvedba strateškega pregleda obrambe je bila pomembna naloga tako Ministrstva za obrambo kot tudi Generalštaba Slovenske vojske v letu 2016 (SPO, 2016). Zadnji tak pregled je bil opravljen v obdobju 2008-2009 (SPOR, 2009), ki je takrat zajel celotni obrambni resor, vključno s podsistemom varstva pred naravnimi in drugimi nesrečami. Vlada Republike Slovenije je 22. decembra 2016 obravnavala dokument in se seznanila s sklepi strateškega pregleda ter določila jasne in konkretne naloge za izboljšanje obrambne sposobnosti in odpornosti Republike Slovenije (VRS, 2016 in MO RS, 2017a) ter glede dviga prihodnjega financiranja obrambnih potreb (VRS, 2017). Pri tem je bila v ospredju namera za zagotovitev nominalne rasti obrambnega proračuna na letni ravni od 20 do 30 milijonov, kar predstavlja letno rast v višini od 5 do 8 odstotkov, pri čemer je doseganje 1,2-odstotnega deleža $\mathrm{BDP}^{3}$ za obrambo prestavljeno v naslednje desetletno obdobje.

$\mathrm{Na}$ podlagi sklepov strateškega pregleda obrambe je oblikovan poseben načrt uresničevanja glavnih ciljev (MO RS, 2017a, str. 5-7), ki se nanašajo na pet smeri delovanja, in sicer: (1) prenovo zakonodaje na obrambnem področju, (2) pregled

\footnotetext{
Kot nekak začetek in izmenjava izkušenj o pripravah na uvedbo strateškega pregleda na MO RS je 11. marca 2016 v Centru vojaških šol v Mariboru potekala mednarodna obravnava vprašanj, povezanih s transformacijo vojsk. Predstavljene so ugotovitve iz nemškega pristopa (general Bühler) in študije slovenskega primera (general Šteiner).

To predstavlja tri petine od zaveze po dvoodstotnem deležu obrambnih izdatkov v zavezništvu.
} 
in prenovo temeljnih dokumentov nacionalne varnosti, (3) preoblikovanje obsega in strukture Slovenske vojske, (4) zagon modernizacije Slovenske vojske in (5) izboljšanje kadrovske sestave Slovenske vojske. Iz načrta Uresničevanja glavnih ciljev iz SPO (prav tam, str. 7) razberemo, da bodo te rešitve vključene v predlog nove resolucije o splošnem dolgoročnem programu razvoja in opremljanja Slovenske vojske (ReSDPRO), pa tudi, da bo postopno preoblikovan koncept pogodbene rezervne sestave. Naknadno je vlada sprejela informacijo in se strinjala z MO RS, da se Resolucija o strategiji nacionalne varnosti ne spreminja (UKOM, 2017, str. 28) ${ }^{4}$.

\subsection{Nacionalni posvet o vlogi rezerve pri zagotavljanju vzdržljivosti obrambno-varnostnih sistemov Slovenije in strokovni posvet o VSR}

V Državnem svetu Republike Slovenije je bil 25. aprila 2016 nacionalni posvet ${ }^{5}$ z naslovom Vloga rezerve pri zagotavljanju vzdržljivosti obrambno-varnostih sistemov Slovenije. Priprave in snovanje posveta so bili povezani z vprašanji reševanja emigrantskega vala konec septembra 2015 in spoznanji o vzdržljivosti nacionalnovarnostnih struktur pri tem in širše. Namen posveta so bile različne predstavitve in razprave o rešitvah $\mathrm{v}$ slovenskem nacionalnovarnostnem ustroju, $\mathrm{s}$ poudarkom na njegovi vzdržljivosti in vlogi rezervnih struktur opozoriti na izzive, dobre in slabe prakse ter rešitve za prihodnost. Posvet je bil odprt za širšo strokovno in civilno javnost. Udeležilo se ga je več kot osemdeset udeležencev (prav tam). Širša javnost je lahko spremljala predstavitve in razprave nastopajočih prek posnetka na nacionalni televiziji. Na posvetu so Državni svet in strokovna ter civilna javnost s prispevki in razpravami presegli ozke resorske okvire in poglede pri obravnavanih vprašanjih. Ker je Ministrstvo za obrambo v tistem času pripravljajo strateški pregled obrambe in spremembe obrambne zakonodaje, je posvet predstavljal neke vrste pogled strokovne in civilne javnosti na vprašanja, povezana z rezervo, konceptom in rešitvami, povezanimi z vojaško strateško rezervo (VSR) ter vzdržljivostjo obrambno-varnostnih struktur v Sloveniji. Posledično je nakazovalo tudi na mogoče spremembe normativne ureditve.

Pripravljeni prispevki, razprave in nadaljnja obravnava teh vprašanj v Državnem svetu $^{6}$ so objavljeni v posebnem zborniku, ki je izšel oktobra 2016 (Šteiner, 2016). $\mathrm{V}$ analizi stanja je bilo oblikovanih več ugotovitev ter navedenih 41 predlogov glede

\footnotetext{
Sprememba Resolucije o strategiji nacionalne varnosti je bil eden od sklepov SPO, ki ga je 22. decembra 2016 potrdila VRS.

Posvet so skupaj z Državnim svetom pripravile Zveza policijskih veteranskih društev Sever (ZPVDS), Zveza slovenskih častnikov (ZSČ) in Zveza veteranov vojne za Slovenijo (ZVVS). Na posvet so bili vabljeni predstavniki iz Urada predsednika republike, poslanci Državnega zbora in svetniki Državnega sveta, obrambno, notranje in zunanje ministrstvo, pristojne službe in organi v njihovi sestavi, vse tri slovenske univerze, Gasilska zveza Slovenije, domoljubne in veteranske organizacije, povezane $v$ Koordinaciji domoljubnih in veteranskih organizacij Slovenije (KoDVOS), ter več deset posameznikov. Na omizjih in v razpravah so sodelovali pet aktivnih predstavnikov Slovenske vojske, trije aktivni predstavniki Policije, trije predstavniki iz akademskega okolja, dva predstavnika Ministrstva za obrambo, sedem upokojenih visokih pripadnikov Slovenske vojske in dva upokojena visoka pripadnika Policije, poveljnik Gasilske zveze Slovenije in štirje drugi strokovnjaki (Šteiner, 2016, str. 20).

6 To je bilo na 73. seji Komisije Državnega sveta za državno ureditev, ki je bila 1. junija 2016 v Ljubljani.
} 
poti naprej. Državni svet je oblikoval sedem predlogov rešitev ${ }^{7}$. V nadaljevanju navajam tiste, ki niso uresničeni in so se nanašali na: (1) prizadevanja za dosego nacionalnovarnostnega konsenza pri urejanju in zagotavljanju kadrovskih, materialnih in zlasti finančnih pogojev za delovanje in vzdržljivost obrambnovarnostnih in zaščitno-reševalnih struktur in njihove rezerve, (2) poziv MO RS in MNZ, da preučita na posvetu predlagane rešitve in pobude ter oblikujeta usklajen seznam sprejemljivih rešitev, (3) določbe koncepta vojaške strateške rezerve in njihovo nadgradnjo $\mathrm{v}$ koncept zagotavljanja rezerv za obrambno-varnostne in zaščitno-reševalne potrebe Republike Slovenije, (4) nadaljnjo razjasnitev idej in zamisli, povezanih z uvedbo t. i. splošne domovinske obveznosti in možnostmi za njihovo uresničitev v praksi (prav tam, str. 40-41).

Poseben strokovni Posvet o vojaški strateški rezervi je potekal 26. oktobra 2017 v Izobraževalnem centru zaščite in reševanja na Igu pri Ljubljani ${ }^{8}$. Na posvetu so obravnavali aktualna vprašanja uresničevanja koncepta vojaške strateške rezerve in vloge domoljubnih in veteranskih organizacij, ki delujejo v javnem interesu na področju obrambe, pa tudi glede zagotavljanja podpore in aktivnosti zvez in društev, s katero se krepita domoljubje in obrambna sposobnost Republike Slovenije. Temeljna ugotovitev na posvetu je bila, da implementacijske aktivnosti pri uresničevanju koncepta vojaške strateške rezerve in Doktrine VSR (MO RS, 2012) po nacionalnem posvetu o teh vprašanjih leta 2016 niso bile intenzivne in se niso spremenile na bolje. Izvedena je sicer prenova koncepta pogodbenih pripadnikov rezervne sestave (PPRS) in koncepta prostovoljnega služenja vojaškega roka (PSVR) ter dopolnjene normativne rešitve, vendar je vse to le prilagoditveno in ne vodi k sistemskim spremembam.

\subsection{Predlog za reformo rezervne sestave Slovenske vojske z vzpostavitvijo Nacionalne garde}

Ena izmed parlamentarnih političnih strank je v začetku leta 2016 predlagala ustanovitev nacionalne garde - rezervne sestave vojske, v katero bi se lahko vključili prostovoljci. Predlog je bil deležen tako odobravajočih kot tudi nasprotujočih odzivov strokovne in splošne javnosti, obravnavan pa je bil tudi na nujni seji parlamentarnega odbora za obrambo, 17. februarja 2016. Predlog in zamisel za oblikovanje nacionalne garde sta izhajala iz analiz varnostne situacije in pojavov ob reševanju migrantske krize v Sloveniji od konca septembra 2015 naprej. Oblikovani predlog (DZ, 2016) je bil usmerjen v reformo rezervne sestave Slovenske vojske, pri čemer bi nacionalna garda nadomestila vse tri dopolnilne oblike popolnjevanja vojske prek PSVR, PPRS in VSR. Po predlogu bi nacionalna garda štela 25.000 prostovoljnih pogodbenih pripadnikov in pripadnic od 18 do 35 let, organiziranih po regionalnem principu $\mathrm{V}$ pokrajinske enote (prav tam).

\footnotetext{
Državni svet je na 41. seji, ki je potekala 8. junija 2016, obravnaval in sprejel zaključke posveta in jih v vednost poslal Vladi Republike Slovenije, Ministrstvu za obrambo in Ministrstvu za notranje zadeve.

$\&$ Na podlagi Programa dela KoDVOS za leto 2017 so na strokovnem posvetu, ki ga je pripravila Zveza slovenskih častnikov, sodelovali predstavniki sedmih domoljubnih in veteranskih organizacij, ki sodelujejo $v$ KoDVOS, svetovalec za obrambo pri predsedniku republike in predstavniki Direktorata za obrambne zadeve MO RS, GŠSV in PSSV.
} 
Zamisel za oblikovanje dvokomponentne sestave Slovenske vojske (vojske in nacionalne garde, op. a.) je izhajala iz izhodišča, da bi nacionalna garda delovala kot dodatne sile Slovenske vojske s točno določeno nalogo v nacionalnovarnostnem sistemu ${ }^{9}$ in le na ozemlju Republike Slovenije. Nacionalna garda bi imela tudi funkcijo dopolnilnih enot pri popolnjevanju s stalno sestavo SV. Vsi pripadniki bi dobili nadomestila v času, ko niso aktivirani, in plačila v času opravljanja vojaške službe ter med urjenjem ${ }^{10}$. O aktiviranju pripadnikov nacionalne garde bi ob spremenjenih varnostnih razmerah odločala vlada, ob velikih naravnih in drugih nesrečah pa minister za obrambo. Pobudo za njeno aktiviranje bi lahko dali tudi župani posameznih občin na območjih, kjer bi nastale spremenjene varnostne razmere oziroma bi bile prizadete $\mathrm{v}$ naravnih in drugih nesrečah (prav tam).

V pestri javni razpravi so se pojavljala številna vprašanja, zakaj opustiti koncept vojaške strateške rezerve in PPRS ter PSVR, zakaj nacionalna garda in ne v preteklosti prepoznavna in uveljavljena Teritorialna obramba. In tudi, ali dvokomponentnost vojske ter predlagane rešitve glede prostovoljnosti, novačenja kadrov in aktiviranja vodijo $\mathrm{v}$ oddaljevanje od doseženih standardov civilnega in parlamentarnega nadzora nad obrambnim sektorjem in vojsko ali celo v ponovno partijsko podrejanje vojaških struktur. Poleg tega so predlagatelji zatrjevali, da za predlagane rešitve ne bi bilo treba spreminjati normativnih in strateških ter planskih dokumentov. Predlog v parlamentarni obravnavi ni dobil podpore, in tako ni prišlo niti do temeljite analize tega vprašanja na MO RS in GŠSV. V tem pogledu je bila usoda predloga podobna usodi ideje o ponovni uvedbi splošne domovinske obveznosti kot inačice posodobljenega naborništva, ki pa se je prebila prek obravnave zamisli na odboru za državno ureditev državnega sveta. ${ }^{11}$

\subsection{Razprave o izzivih in prihodnjem razvoju ter obsegu vojske v Sloveniji}

Prihodnost Slovenske vojske je bila tema posebnega posveta, ki ga je 28. marca 2017 pripravil in izvedel Generalštab (GŠSV, 2017a). Posvet je bil bolj kot notranji strokovni javnosti in njihovi razpravi namenjen nastopom nekdanjih načelnikov vojske v Sloveniji, predstavnikom akademske sfere ${ }^{12}$ in svetovalcem na strateški ravni upravljanja obrambno-vojaškega sistema. $\mathrm{V}$ resnici je bilo to posvetovanje o ugotovitvah strateškega pregleda obrambe in dveh skupinah vladnih usmeritev, povezanih $\mathrm{s}$ tem. $\mathrm{V}$ prvi skupini so bile usmeritve in vprašanja o izboljšanju učinkovitosti delovanja in prenovi resolucije o strategiji nacionalne varnosti, obrambne strategije in resolucije o splošnem dolgoročnem programu razvoja in opremljanja SV (ReSDPRO) ter nove sistemske rešitve v normativni ureditvi. V drugi

\footnotetext{
Namenjene bi bile nadzoru teritorija, obveščevalno izvidniški dejavnosti, zaščiti kritične infrastrukture, pomoči ob naravnih in drugih nesrečah in civilno-vojaškemu sodelovanju.

${ }^{10}$ V teh primerih bi bili pripadniki nacionalne garde izenačeni s pripadniki stalne sestave $\mathrm{SV}$.

"I Glej tč. 1.2 tega poglavja.

${ }_{12}$ Na posvetu so nastopili trije nekdanji načelniki vojske, štirje predstavniki obramboslovne in varstvoslovne znanosti, svetovalci predsednika republike, vlade in načelnika Generalštaba ter generalni direktor DOP/MO RS. Na posvetu so bili tudi vodstvo Slovenske vojske z načelnikom Generalštaba in sodelavci ter načelniki sektorjev, ki pa niso aktivno sodelovali.
} 
skupini so bile problematika financiranja vojaških potreb in realnost izboljšanja tega stanja, dinamike in pričakovanj (prav tam).

V razpravah je bilo izpostavljeno, da je bil posvet pripravljen in izveden nekaj let prepozno. Izpostavljena pa so bila tudi vprašanja političnega konsenza za predlagane in nujne ukrepe, stabilnosti v vojski za realizacijo ukrepov, vprašanja statusnega urejanja vojaškega poklica in socialne varnosti ter plač vojaških oseb, negativne ocene o pripravljenosti vojske, posledic ekonomske krize in zmanjševanja vlaganj v obrambni sistem in vojsko in vprašanja strokovne avtonomije vojske ter ustreznosti vojaških nasvetov (GŠSV, 2017b).

Hkrati je bila izpostavljena nujnost širjenja vedenj o pomenu uravnoteženosti delitve bremen v zavezništvu, nacionalnih ambicij in glede materialnih, finančnih in kadrovskih virov, pri slednjih pa pomen kariernih poti in primerljivega kompetenčnega modela. Poleg pozitivnih ocen o razpravah je bilo slišati tudi kritične pripombe nanje. V svojem nastopu sem izpostavljal, da bi bilo dobro vedeti, ali s(m)o v krizi financiranja, ali sta kritični organiziranost in struktura, ali smo v kadrovski krizi oziroma krizi voditeljstva in menedžmenta. V zahvali Generalštaba sodelujočim na posvetu je bilo navedeno tudi, da bodo mnenja in predloge upoštevali pri mnogih premislekih o oblikovanju novih izboljšanj za Slovensko vojsko (prav tam).

Opisanemu je sledil strokovni Posvet o bodoči organizaciji in obsegu Slovenske vojske, ki ga je Generalštab pripravil in izvedel 21. aprila 2017. Na tem posvetu strokovna javnost ni sodelovala, ampak le generali in najvišji častniki ter nekateri poveljniki SV (GŠSV, 2017c). Ti so v strokovni razpravi obravnavali izhodišča za učinkovito in kakovostno organizacijo in obseg vojske v prihodnje. V ospredju obravnave so bili pripravljeno gradivo o konceptu delovanja do leta 2030 in štiri različice obsega in strukture ${ }^{13}$. Preostala tematska področja posveta so bila namenjena značaju prihodnje vojne in vojskovanja SV, vzpostavljanju zmogljivosti in doseganja ciljev zmogljivosti, popolnjevanju vojske in upravljanju kadrovskih virov, strukturnim in konceptualnih vidikom združenega bojevanja, pridruževanju in povezljivosti s skupnimi zavezniškimi strukturami, organizaciji in strukturam logistične podpore. Iz dostopnega gradiva (prav tam, str. 10-11) lahko razberemo še več odprtih vprašanj in izzivov. Pomemben zaključek posveta se je nanašal na nadaljnjo organizacijo še dveh podobnih posvetov in opredelitev tematskih področij, ki jih je bilo treba obdelati ali ponovno preučiti, ter pripravi dodatnih različic obsega in strukture vojske ${ }^{14}$. Glede pripravljenih in analiziranih različic obsega in strukture vojske ugotovimo, da vse temeljijo na trenutnem obsegu do 10.000 oseb z različnimi strukturnimi variacijami med stalno in rezervno sestavo.

${ }_{13}$ V ta namen je bila v GS̆SV oblikovana posebna 30-članska skupina častnikov, ki je v dveh podskupinah od februarja do konca marca 2017 z uporabo več domačih in tujih orodij, analiz in vojnih iger preverjala trenutni obseg in strukturo SV in oblikovala njihove različice za prihodnost (GŠSV, 2017c).

${ }_{14}$ Prvi je potekal na GŠSV septembra, na drugem pa so bile sprejete tudi odločitve o različici prihodnje strukture Slovenske vojske. 


\subsection{Razprave ob pripravi sprememb Zakona o obrambi in Zakona o službi v Slovenski vojski}

Normativno urejanje obrambno-vojaškega področja je z vidika sistemskega spreminjanja in vzpostavljanja ustreznih podlag zanje zelo pomembno. Priprava Zakona o obrambi in Zakona o službi v Slovenski vojski je potekala hkrati od jeseni 2015 naprej $^{15}$. Izhodišča in potrebe po spremembah so bile predstavljene tudi $\mathrm{V}$ javnosti, k snovanju normativnih rešitev sta bili že decembra 2015 povabljeni tudi notranja in širša strokovna javnost. Javna predstavitev predlogov rešitev s predstavniki domoljubnih in veteranskih organizacij je bila izvedena v Izobraževalnem centru na Igu 13. maja 2016. Sodelujoče organizacije so bile povabljene k pripravi pisnih predlogov ${ }^{16}$, zatem pa se je usklajevanje normativnih rešitev preusmerilo predvsem na sindikate v obrambnem resorju ${ }^{17}$. Z nekaterimi subjekti strokovne javnosti so na MO RS leta 2017 potekala tudi individualna usklajevanja in obravnave pripravljenih predlogov ali odprtih vprašanj. Iz informacij, ki so prišle v javnost, lahko sklepamo, da je bilo zelo zapleteno tudi medresorsko usklajevanje pripravljenih rešitev. ${ }^{18}$ Obseg sprejetih pripomb iz strokovne javnosti je bil majhen ${ }^{19}$, javne razprave pa se niso premaknile zunaj okvirov političnih strank. Ob zapletu glede potrditve predlogov zakonov na Vladi Republike Slovenije so upokojeni brigadirji in generali 25. avgusta 2017 podpisali javno pismo predsedniku vlade glede pomembnosti in potrebnosti posodobitve normativne ureditve obrambnega področja ter predvsem za izboljšanje statusa poklicnih vojakov in izenačenje s statusom policistov v Sloveniji (pismo, 29. 8. 2017). Januarja 2018 sta bila zakona v parlamentarni proceduri.

\subsection{Strateško načrtovanje in cilji zmogljivosti Slovenske vojske 2017}

Na podlagi sklepov SPO so na Ministrstvu za obrambo za leto 2017 predvideli tudi pregled strateških dokumentov, ki jih označujejo s temeljnimi strateškimi usmerjevalnimi in planskimi dokumenti (MO RS, 2017a, str. 4). Na Ministrstvu za obrambo in Generalštabu Slovenske vojske so tako pristopili k preučitvi in pripravi sprememb Resolucije o strategiji nacionalne varnosti in Obrambne strategije Republike Slovenije. Spreminjanje strategije nacionalne varnosti je, kot sem že navedel, opuščeno. Kam so usmerjene spremembe obrambne strategije, v javnosti ni bilo predstavljeno, znane so le javno dostopne ugotovitve strateškega pregleda obrambe. Tudi sodelovanje strokovne javnosti je bilo zelo omejeno.

\footnotetext{
${ }_{15}$ Glej Dnevnik, 13. 5. 2016 in MO RS, 2017 b.

${ }^{16}$ Zveza slovenskih častnikov je k zbiranju in oblikovanju predlogov pristopila resno, in sicer so prišli predlogi iz vrst zaposlenih v vojski in tudi nekdanjih pripadnikov vojske. Oblikovano je več kot sedemdeset predlogov sprememb z ustreznimi pojasnili. Poleg urejanja vprašanj profesionalizacije in statusnega urejanja vojaškega poklica so bila v ospredju še vprašanja nalog vojske, vloge in imenovanja načelnika vojske, povišanj in disciplinskih ukrepov. Predstavljena so bila tudi opozorila na rešitve, ki po oceni posebne delovne skupine ZSC̆ ne prinašajo napredka.

17 Glej Dnevnik, 13. 5. 2017.

${ }_{18}$ Glej Delo, 17. 7. 2017.

${ }^{19}$ Iz obravnave tega vprašanja na sestanku vodstva ministrstva s predstavniki domoljubnih in veteranskih organizacij, ki sodelujejo v KoDVOS, 18. junija 2017, smo lahko iz izjave ministrice razbrali, da so od strokovne javnosti pričakovali več in boljše predloge.
} 
V prvi polovici leta 2017 so bili končani tudi načrtovanje in programiranje ter pogajanja o zavezniških ciljih zmogljivosti, ki vplivajo na razvoj Slovenske vojske v srednjeročnem obdobju do leta $2023^{20}$. Pri tem je programiranje dveh najpomembnejših vojaških zmogljivosti, ki jih je treba vzpostaviti, zastavljeno tako, da se cilj za oblikovanje prve bataljonske bojne skupine doseže v naslednjih šestih letih, torej do leta 2022, medtem ko je za drugo bojno skupino postavljeno ciljno leto 2025 (MO RS 2017a). Posledično je bilo treba dopolniti tudi Srednjeročni obrambni program za obdobje 2016-2020 (SOPR 2016-20).

$\mathrm{V}$ času procesa načrtovanja in programiranja oblikovanja zmogljivosti so $\mathrm{V}$ Generalštabu na podlagi na vladi sprejetih zavez analizirane tudi tri različice mogočega financiranja obrambnih potreb Slovenije in postavitve zmogljivosti vojske do leta 2029 (GŠSV, 2017c). Nedvoumna je ugotovitev, da nobena izmed obravnavanih projekcij ne omogoča razvoja v obsegu, ki bi omogočil postavitev sprejetih ciljev zmogljivosti v dogovorjenih rokih. Hkrati to pomeni, da državi ne bo uspelo oblikovati vojaške zmogljivosti za nacionalno obrambo in posledično tudi ne prispevati k skupnim zmogljivostim v zavezništvu. Ta ugotovitev najbolj kliče po družbenem in političnem konsenzu glede financiranja in prihodnjega reševanja obrambno-vojaških potreb.

\subsection{K sklepu}

Ugotovim lahko, da je znotraj obrambnega sistema v preteklih dveh letih opravljeno veliko dela tako glede normativnega urejanja kot tudi obrambnega načrtovanja in načrtovanja sil. Posledično so se začele tudi že implementacije nekaterih rešitev v strukturi vojske, pa tudi v njenem obsegu, kar je zlasti posledica večjega odliva kadrov v primerjavi s prilivom. Če zanemarim opisani primer projektiranja strukture in obsega vojske do leta 2030, čeprav so strateška izhodišča v SDPROSV-25 (2011) postavljena le do leta 2025, lahko sklenem, da je dinamika dejavnosti zares izjemna. Pri tem je treba izpostaviti tri zadeve.

Prva izhaja iz frazema, po katerem ni tako pomembno, kako veliko delo opraviš, ampak koliko in kaj je od tega ustrezno. Seveda bodo skeptiki in kritiki v opisanem primeru izpostavljali predvsem domnevno neustrezne rešitve in jih na tehtnici rezultatov med kakovostjo in količino ali ustreznostjo in neustreznostjo postavljali na nasprotno stran od ustreznih rešitev. Druga izhaja iz dvoma, ali so zajeti vsi pomembni vidiki sprememb. Slovenska obrambno-vojaška praksa je v preteklosti polna primerov hitenja in nedokončanih rešitev, tudi dobrih. Pri tem so nekatere opuščene, ker niso bile dovolj premišljene in pred začetkom implementacije preverjene, ali pa zato, ker je bilo treba biti v dinamiki sprememb, ne ozirajoč se

\footnotetext{
${ }^{20}$ Iz predstavitve sprejetih ciljev zmogljivosti na novinarski konferenci 13. marca 2017 (MO RS 2017a) razberemo, da so kot prednostni cilji sprejeti (a) postavitev dveh srednjih bataljonskih bojnih skupin, vzdrževanje zdravstvene zmogljivosti Role 2, (c) ustrezni komunikacijski in informacijski sistemi, (c) kibernetska obramba, (d) sile za specialno delovanje in (e) zmogljivosti za usmerjanje zračne podpore. Pri tem je izpostavljeno, da bi za prvi cilj, in sicer za oblikovanje dveh mehaniziranih bataljonov kot osnovnega gradnika bojnih skupin, potrebovali približno dve tretjini sredstev oziroma 600 mio evrov.
} 
na njihovo ustreznost, sprejemljivost in končni izid ali stanje. Omenim naj še tretjo zadevo, ki obravnava, ali so pripravljene rešitve dovolj vizionarske oziroma le v duhu časa in političnega pragmatizma, da se več in bolje ne da. Gre za dilemo, povezano z vizijo in vprašanjem, kdo je njen snovalec in ali njegov pogled seže dlje od mandata ene izvršilne oblasti in političnega konsenza, ki se ga za spremembe lahko doseže tudi zunaj vsakokratnih koalicijskih okvirov.

V Sloveniji smo v obdobju, ko je večina dejavnosti normativnega urejanja obrambnovojaških vprašanj, sprememb strateških dokumentov ter razvojnih načrtov končanih in se čaka na odločitve za implementacijo in na rezultate. Nekateri so pri tem tudi neučakani in bi hoteli rezultate, še preden se je implementacija začela. Sodobna orodja in metode pri tovrstnih aktivnostih, programiranju in načrtovanju tudi kompleksnim sistemom in soodvisnim rešitvam omogočajo vmesno preverjanje rešitev in morebitnih izhodov. Temu je v nadaljevanju namenjena tudi razprava o tem, ali gre za transformacijske ali le preživitvene oziroma tranzicijske izzive oziroma ali imamo za pripravljene ali mogoče rešitve prave odgovore na vsa pojavljajoča se vprašanja.

\section{O TRANSFORMACIJSKIH ALI PREŽIVETVENIH IZZIVIH}

Ko sem se ukvarjal s študijo transformacije vojske $\mathrm{v}$ slovenskem primeru in to tudi publiciral (Šteiner, 2016), sem poskušal prepoznati in pojasniti slovenske transformacijske izzive. V pripravah za sodelovanje na že omenjenem posvetu Prihodnost Slovenske vojske sem preverjal, ali so oziroma če so še vedno uporabni. Pri tem jih s pomočjo vprašanja, ali gre za transformacijske ali preživetvene izzive v nadaljevanju ponovno obravnavam.

Viri in nacionalnovarnostna politika so osrednji izziv, ki je povezan tudi s stvarnostjo, iz katere izhaja, da dogovorjenega in želenega dvoodstotnega deleža družbenega bruto proizvoda za obrambne izdatke slovenski državi še nekaj časa ne bo uspelo zagotoviti. Slovenska politika bo morala poiskati odgovor na to, koliko virov za obrambne potrebe je v resnici pripravljena zagotoviti oziroma jih bo mogoče zagotoviti. Zagotovitev finančnih virov in njihovo uravnoteženje med potrebnimi in mogočimi sta podlaga za odgovore na vprašanja, kako naprej, kako uresničiti spremembe obrambno-vojaškega področja in vojske znotraj nje. Odgovor o možnosti zagotovitve virov je osrednje in ključno vprašanje upravljanja vojske in razmerja med zakonodajno oblastjo, ki postavlja politiko in cilje, ter izvršilno oblastjo, ki skrbi za njihovo doseganje in izbiro ustreznih poti. Dejstvo je, da se je v praksi dogovorjena zaveza ob vstopu v zavezništvo praktično prepolovila. Zato so odločitve o virih in nacionalnovarnostni politiki osrednji in izjemen izziv.

Poleg tega bo v slovenskem primeru treba najti politični konsenz in izbrati tudi pristop $\mathrm{k}$ spremembam. Zadnja tri leta se $\mathrm{v}$ obrambnem sistemu praktično več ne govori in ne uresničuje pomembnih sprememb, povezanih s transformacijo. Predlagane normativne rešitve in priprava sprememb strateških dokumentov in razvojnih načrtov so prej preživitvene kot reformne ali celo preobrazbene. Tudi sprejemanja 
zavezniških ciljev vojaških zmogljivosti ob jasnem vedenju, da jih v postavljenih okvirih ne bo mogoče uresničiti, je neprimerno prelaganje obvez v prihodnost. Mednarodna skupnost dejstva, da nam gre v Sloveniji gospodarsko dobro, kljub temu pa nam ne uspe obrambno-vojaških potreb ustrezno financirati, ne razume in ga ne more (več) odobravati.

Alternative sedanjemu konceptu obrambne organiziranosti so izziv, povezan z vprašanji, ali v Republiki Sloveniji nadaljevati dihotomijo oziroma trihotomijo $\mathrm{v}$ obrambno-vojaški in civilnozaščitni organiziranosti ali opraviti temeljite sistemske posege in konceptualne spremembe. Vprašanje je tudi, kako opustiti ali bolje nadgraditi dosedanje rešitve in opustiti arhaične ostanke iz koncepta, nastalega pred petindvajsetimi leti, oziroma kako ga nadgraditi in bolj prilagoditi civilnokriznemu upravljanju. Kako ga izpeljati in katere nujne naloge in sistemske rešitve uresničiti v prehodnem obdobju? Smo pri nedavni pripravi zakona o obrambi zamudili priložnost za sistemske rešitve in odgovor na vprašanje o novem slovenskem obrambnovojaškem in zaščitno-reševalnem konceptu?

$\mathrm{O}$ vidikih integriranja s sistemom varstva pred naravnimi in drugimi nesrečami $\mathrm{v}$ sistemskem pogledu v Sloveniji še ni bilo dovolj strokovnih razprav, pa tudi politične in druge zamisli so praviloma trčile ob visoke ovire avtonomije teh dveh področij. Če posodobljena integracija ni uresničljiva, še vedno ostane vprašanje o usklajenem oblikovanju zmogljivosti za doseganje racionalnosti in da bi se izognili podvajanju ${ }^{21}$.

Nekatera vprašanja integriranja na nacionalni ravni so lahko tudi odpiranje pandorine skrinjice. Na to opozarjajo praksa normativnega urejanja $\mathrm{v}$ varnostnem sektorju in rešitve statusa policistov $\mathrm{v}$ primerjavi s pripravljenimi rešitvami v obrambnem sektorju ter pri statusu vojaka. Pri tem se od usklajenega ali povezanega reševanja bolj oddaljujemo kot približujemo, saj se sprejemajo nekatere celo antagonistične rešitve.

Prihodnja namembnost in značaj obrambnih sil sta poseben transformacijski izziv, ki je tako politične kot konceptualne narave, s številnimi izvedbenimi značilnostmi. Povezan je z vprašanji, za katere namene se bodo prihodnje obrambno-vojaške strukture uporabljale, zlasti pri novih ogrožanjih, na primer v kibernetski obrambi, zaščiti kritične in energetske infrastrukture, protiterorizmu ali protipiratstvu ali celo za obvladovanje migracijskih tokov. Odgovori na številna vprašanja o kibernetski obrambi, kibernetskem delovanju in kibernetski varnosti v najširšem pomenu so še vedno precejšnja neznanka.

Ob tem se pojavlja vprašanje, kako bo vse to vplivalo na opredelitev temeljnih nalog Slovenske vojske. Posledično je izziv v slovenskem primeru povezan s prihodnjim značajem vojske in njenim organizacijskim modelom. Pri tem se srečamo še s številnimi drugimi dejavniki, kot so univerzalnost proti specializaciji, večnamenskost opreme

\footnotetext{
${ }^{21}$ Poseben primer je vprašanje integrirane obalne obrambe, pri kateri je uvedeno usklajevanje služb med avtonomnimi subjekti in ministrstvi ter zmogljivostmi, ki uspešno delujejo. Pri integraciji bi bilo treba doseči še večjo sinergijo med ministrstvi in drugimi ustanovami, kar bi prispevalo $k$ racionalizaciji stroškov in izrabe virov.
} 
proti izključni rabi za vojaške potrebe, modularnost in sposobnost hitrega prilagajanja struktur ter delovanja v širokem okviru nalog za nacionalno obrambo, v mednarodnem okolju, pri podpori zaščiti in reševanju ter pomoči drugim državnim organom.

Pri namembnosti vojske je treba opozoriti še na vprašanje pravega razmerja med strukturami in delovanjem $\mathrm{v}$ mednarodnem okolju $\mathrm{v}$ primerjavi $\mathrm{z}$ nalogami in delovanjem $\mathrm{v}$ nacionalnem okolju. Transformacijski trendi in prizadevanja $\mathrm{v}$ zavezništvu in tudi v EU povečujejo težnje in zahteve po tem, da se oblikuje vedno več večnacionalnih sestav in zmogljivosti. Na drugi strani pa pri številnih zavezniških državah v Evropi ugotavljamo, da so trendi na nacionalni ravni usmerjeni predvsem v bolj združeno in povezano uporabo zmogljivosti različnih podsistemov v nacionalnem okolju. Vse to zahteva drugačno funkcionalno povezanost in usposobljenost, vpliva pa tudi na procese opremljanja in modernizacije.

Nadaljevanje integracije in sledenje zavezniškim transformacijskim oziroma skupnim prizadevanjem je izziv, ki ni usmerjen v »vprašanje, da ali ne«, o nadaljnjem sodelovanju v zavezniških prizadevanjih in sledenju vojaški integraciji med zaveznicami, temveč $v$ to, kako to izboljšati. Temu je posebej namenjen trend pametne obrambe, ki se odziva na pojav finančnih omejitev in išče rešitve za izboljšanje učinkovitosti, ohranjanje vojaške relevantnosti in sposobnosti za nove varnostne izzive. Dodati je treba posebno občutljiva vprašanja o projektih združevanja in souporabe $v$ EU.

Odnos do tehnološkega dejavnika in vprašanj modernizacije je izziv, ki se nanaša na tehnološko bazo in možnosti za njeno posodabljanje, predvsem v pogledu informatizacije in digitalizacije kot pomembnega izhodišča za transformacijo. Izziv je povezan tudi s prizadevanji za izenačitev tehnološke baze obrambno-vojaških sistemov zavezniških držav, da bi skupne transformacijske pobude, programi in koncepti lahko uspeli. Slovenski izziv ob tem je, kako obdržati Slovensko vojsko v srednjem tehnološkem kakovostnem razredu, kot je bilo in je v strateških razvojnih načrtih še vedno zastavljeno, kajti v nižjem tehnološkem kakovostnem razredu ne bi mogli slediti pomembnim pobudam, projektom, konceptom in programom, ki vplivajo na transformacijo in prinašajo dodano vrednost. Izziv modernizacije je povezan še z večnamensko uporabnostjo opreme, ki mora, kot je že izpostavljeno, omogočiti Slovenski vojski sodelovanje pri zaščiti, reševanju in pomoči civilnemu prebivalstvu ob nesrečah. To s svojimi zahtevami v nekaterih primerih povečuje nabavne stroške ali oddaljuje slovenske nakupe od skupnih projektov opremljanja, ki so tako zelo zaželeni v Evropski obrambni agenciji.

Organizacijski koncept in struktura vojske sta predvsem strokovno izjemno zahteven in zapleten izziv, ki je, sodeč po številnih dosedanjih reorganizacijah in preoblikovanjih vojaških struktur v Sloveniji, tudi med najbolj izpostavljenimi in ne le v praksi, temveč tudi v strokovnih in laičnih razpravah, zelo priljubljen. Pri tem najbolj izrazitem transformacijskem vidiku izziva o konceptu in strukturi vojske navajam vprašanja, kateri rodovi in organizacijske strukture bodo sestavljali 
prihodnjo slovensko vojaško organizacijo in kateri bodo izginili oziroma jih bo treba preobraziti, da skoraj ne bodo več prepoznavni.

Slovenska značilnost je še vedno tudi zelo razvejana in obsežna struktura poveljevanja. Zato je umestno vprašanje, kaj narediti s polkovno in brigadno strukturo v odnosu do poveljstva sil in kakšen je odnos med operativno in taktično ravnijo. Poleg tega so pomembna tudi vprašanja, povezana $\mathrm{z}$ racionalizacijo in integracijo na nacionalni ravni ter z iskanjem rešitev za stroškovno vzdržnost struktur in funkcij, kar se dotika slovenske predimenzioniranosti civilnega, pa tudi upravljavskega in poveljniškega dela obrambno-vojaških struktur.

Vloga in razvoj ter vzdrževanje strateške rezerve in rezervnih sil so poseben izziv. V slovenskem primeru se je pojavljal v konceptualnem in strukturnem ter funkcionalnem pomenu ves čas razvoja vojske. Izziv je kratkoročno povezan z uresničevanjem že sprejete Doktrine vojaške strateške rezerve (MO RS, 2012), ki v konceptualnem smislu odgovarja na navedena vprašanja, v izvedbenem pogledu pa prizadevanja usmerja bolj v organizacijske in strukturne rešitve. Del teh rešitev je uveljavljen s preoblikovanjem Slovenske vojske leta 2013, predvidena nadgradnja v prihodnosti pa izpostavlja vprašanje o vračanju na dvokomponentno strukturo vojske ali v strukturo prostorskih poveljstev in poveljstev premestljivih enot.

Poseben izziv je povezan z odnosom in dejavnostmi za vzdrževanje rezervnih sil in ohranjanje njihove pripravljenosti, ki je v slovenskem primeru precej oddaljen od $\mathrm{v}$ načrtih postavljenem obsegu.

Zagotovitev profesionalizacije vojske kot procesa je v slovenskem primeru pomembna, ker je profesionalna vojska eno izmed pomembnih izhodišč pri uresničevanju zavezniških transformacijskih trendov. Pri tem je treba upoštevati predvsem vprašanjauvedbe tistih vidikov strukturne in funkcionalne profesionalizacije, ki še niso povsem uresničeni. Kratkoročno bo treba rešiti odprta vprašanja pogodbenih delovnih razmerij. Bolje kot do zdaj bo treba poskrbeti za odhode iz vojske, pa tudi za odgovore na vprašanja, povezana z upokojevanjem in reintegracijo pogodbenih pripadnikov v civilnodružbeno in delovno okolje. Prav tako so za profesionalizacijo vojske zelo pomembne notranja gibljivost in tekmovalnost kadrov ter uveljavitev kompetenčnega modela, kot ga poznajo v vojskah z daljšo tradicijo.

V povezavi s profesionalizacijo je tudi vprašanje, kako zagotavljati ustrezno izobražen kader in vojaškostrokovno usposabljanje zanj. V zadnjem času so se okoliščine, tudi zaradi uvajanja rešitev po bolonjskem sistemu in priseganja na nacionalne poklicne kvalifikacije, spremenile ${ }^{22}$. Zato izpostavljam vprašanje, kako sedanji slovenski vojaški izobraževalni sistem še bolj integrirati v civilnega in kako naj postane bolj avtonomen.

\footnotetext{
${ }_{22}$ Sistem varstva pred naravnimi in drugimi nesrečami je v obdobju 2009-2012 uspelo uvesti v srednje- in višješolsko izobraževanje za poklicne gasilce.
} 
Sposobnost transformiranja in podpora transformaciji pomenita izziv, povezan z vprašanji o tem, kako podpreti in omogočiti njuno uresničitev. Med najpomembnejšimi pogoji za uresničitev transformacijskih izzivov in prihodnjih nalog v slovenskem obrambno-vojaškem sistemu sta politični mir in podpora, vključno z že omenjenim racionalnim in stabilnim financiranjem. Pomembno pa je tudi vedeti in pojasnjevati, katere posege bo treba narediti za tako zahtevne spremembe, tudi zaradi ljudi $\mathrm{v}$ sistemu, ki naj bi transformacijo najprej razumeli ter v njej prepoznali vsaj nekaj sprejemljivih ciljev, da bi lahko prispevali k sinergiji, ki je za uspeh transformacije nujna. Brez notranjega oziroma organizacijskega prispevka sinergičnih učinkov ni mogoče doseči. Poleg tega je tu še vprašanje ustvarjanja razmer za spremembe v obrambnem sistemu in širše.

Naj sklenem ta del predstavitve izzivov, ki so navedeni kot transformacijski. Od tega, kateri bodo vključeni in kakšen bo učinek njihove implementacije, je odvisno, ali bodo učinkovali le kot preživetveni. Izpostavljena vprašanja omogočajo, da pripravljene rešitve analiziramo in pridemo do potrebnih odgovorov, še preden bomo soočeni z rezultati.

\section{RAZPRAVA}

Kot sem ugotavljal v študiji slovenskega transformacijskega primera (2016, str. 20), je slovenska posebnost, da se z vprašanji konsolidacije države in odprave oziroma dokončne rešitve odprtih zadev iz tranzicijskega obdobja niso prenesle na celotno družbeno področje. Posledično so na vrhuncu gospodarske krize po letu 2012 tudi vnema in aktivnosti za transformacijo Slovenske vojske realno ugasnile oziroma se je $\mathrm{s}$ transformacijo označevalo to, kar ne spada v pravo preobrazbo obrambno-vojaških sistemov (prav tam, str. 191-192 in 318). Preživitvena praksa je nekatere aktivnosti, zlasti na področju nadaljnje profesionalizacije vojske in njenega strukturnega preoblikovanja in preobrazbe obrnila v povsem nasprotno smer. To potrjujejo tudi ugotovitve iz SPO 2016 (str. 2), ki opozarjajo na zadeve in področja, ki so se v primerjavi z ugotovitvami o pomanjkljivostih ob SPOR 2009 še poslabšali.

Poleg tega pa je premalo učinkovito odzivanje na spremembe na trgu delovne sile in zagotavljanje konkurenčnosti vojaškega poklica ne le v primerjavi z drugimi, temveč predvsem $\mathrm{v}$ primerjavi z uniformiranimi poklici $\mathrm{v}$ javnem sektorju skoraj ohromilo popolnjevanje vojske in kadrovska gibanja. $\mathrm{K}$ temu je pripomoglo tudi javno izpostavljanje, da je pripravljenost vojske več let ocenjena $\mathrm{z}$ negativno oceno. Strateški in komunikacijski pristop, da se bosta zaradi poudarjanja pomanjkljivosti in slabih ocen sama po sebi izboljšala financiranje in odnos politike ter javnosti do tega vprašanja, sta bila povsem zgrešena. Poleg tega v praksi niso bili ne predstavljeni ne izvedeni učinkoviti ukrepi za izboljšanje stanja in sankcije do odgovornih ${ }^{23}$. Dobro bi bilo razjasniti, komu je v resnici ustrezalo takšno stanje? V javnosti izpostavljeni primeri trenj med vodstvom ministrstva in vodstvom vojske bi lahko opozarjali

\footnotetext{
${ }^{23}$ Prav neverjetno je, da se Svet za nacionalno varnost ni niti enkrat sestal za obravnavo vprašanj bojne pripravljenosti vojske, čeprav je bila ta tri leta zapored ocenjena z negativno oceno.
} 
na težave pri civilnem nadzoru nad vojsko, na vplive vzporednih centrov moči in medsebojnim nerazumevanjem oziroma ukvarjanjem obeh subjektov samim s seboj.

Ena od osrednjih posebnosti na obrambno-vojaškem področju je bilo izpostavljanje problematike ustreznega financiranja obrambnih potreb in rešitve $\mathrm{v}$ uradno sprejetih strateških dokumentih in razvojnih načrtih. Je bila to ključna zadeva, ki je transformacijo vojske v Sloveniji potisnila na obrobje in vojsko postavila v položaj boja za golo preživetje? Dejstvo je, da je Slovenija iz primera dobre prakse majhne države na področju preobrazbe obrambno-vojaškega sistema v zavezništvu v zadnjih treh letih pristala na repu kazalnikov, ki jih uporabljajo bodisi pri institucionalnem bodisi pri strokovnem ocenjevanju stanja vojaških struktur in zmogljivosti ter napredka obrambno-vojaških sistemov.

Pripravljene zakonske rešitve ne prinašajo strateških sprememb v strukturi in poslanstvu vojaških sil in glede izboljšanja oblikovanja vojaških zmogljivosti in zlasti kadrovskih ter drugih virov. Zato se o viziji in strategiji oziroma poti za njeno uresničitev $\mathrm{v}$ Sloveniji bolj kot kdaj koli prej razhajamo. Kot sem omenil v prispevku, se spremembe zakonodaje, strateških razvojnih in planskih dokumentov, programiranje strukture in obsega vojske ter njenih zmogljivosti pripravljajo na trenutno zasnovo in koncept obrambno-vojaške organiziranosti. Del strokovne javnosti govori o prepotrebni prenovi ali celo o preobrazbi, pa tudi o novem pristopu, opredeljenem v tako imenovani »beli knjigi«, ki naj bi povsem na novo začrtala pot za naprej. Ni mogoče spregledati niti tistih, ki si prizadevajo, da se ta del državne strukture dokončno marginalizira in postane povsem nepomemben. Zaskrbljujoče je, da v obstoju države Slovenije nikoli ni bilo večjega neskladja med deklariranim izpostavljanjem pomena in potrebnosti vojske na eni in politično prakso na drugi strani.

V obdobju pridruževanja Republike Slovenije zavezništvu in vojaški strukturi EU do leta 2004 in zatem v procesu integracije v Nato do leta 2010 je Slovenska vojska imela jasne cilje, ki so bili tudi doseženi. Proces transformacije je bil v zagonu in pri tem so bili doseženi pomembni rezultati ter konsolidirane zadeve in odpravljene strukturne pomanjkljivosti iz obdobja tranzicije. Ekonomska kriza je razvoj vojske skoraj povsem ustavila, smer transformacijskih sprememb pa se je obrnila nazaj v tranzicijske ali bolje preživetvene. Ob tem političnih elit spremembe vizionarskega tipa niso zanimale, niti jih niso bili pripravljeni sprejeti, kaj šele začeti uresničevati. Zdaj smo priče nastalim razmeram in stanju v vojski, pa tudi pričakovanjem, da se bodo zadeve zelo hitro izboljšale. Prav to vodi pripravljavce rešitev v vedno nove zagate, ko so pred izzivi, ki jih ni mogoče uresničiti, dokler se ne konsolidira stanje in celovito pripravijo razmere za temeljite spremembe. Zaskrbljujoče je dejstvo, da politične in tudi strokovne avtoritete poskušajo ovirati oblikovanje in prevzemanje odgovornih dolžnosti novim vojaškim kadrom. Tako se namreč prepad med nosilci vizij in strategij zanje in preostalim voditeljskim kadrom v vojski le poglablja.

Vedno več je analitikov in strokovne javnosti, ki menijo, da je treba na obrambnovojaškem področju zastaviti novo vizijo in iz nje izhajajoče cilje in vzpostaviti 
vodstvene strukture za njeno uveljavitev. Tem pričakovanjem sledi tudi laična javnost, ki ima še vedno zelo pozitiven odnos do vojske, njenih nalog in delovanja, hkrati pa je tudi tolerantna do pomanjkljivosti in težav. Slišati je, da bi ob naborniškem načinu popolnjevanja lažje zagotovili potrebe po kadrih, saj bi jih dobili z zakonsko zavezo oziroma na njem temelječo prisilo. Strokovna javnost pri tem ne ponudi jasne slike dejanskega stanja in možnosti.

Pomembno bi bilo vedeti, ali smo se po koncu gospodarske krize v obrambnem resorju in vojski, kljub opisani dinamiki, resno lotili konsolidacije stanja, in sicer pomanjkljivosti v strukturi, bodisi tistih, ki so povezane s trgom delovne sile, nadaljnje profesionalizacije vojske ali stabilizacije socialnega in statusnega položaja vojaškega poklica. Še vedno je premajhen napredek v modelu ustvarjanja profesionalne vojske, in sicer v širokem naboru rešitev, povezanih z izhodi kadrov iz sistema in njihovega zadrževanja, upokojevanja, šolanja, napredovanja in zlasti zmanjševanja strukturnih neskladij. Pri urejanju plač v vojski se izpostavlja problem motivacije, ki je dejanski, ne rešuje pa se kot vzvod za trg delovne sile.

Posebnost Slovenije v pogledu financiranja in oblikovanja vojaških zmogljivosti, ki traja že dve desetletji, je, da so cilji zmogljivosti (pred tem cilji sil in partnerski cilji sil) gonilo razvoja. Vendar je večina naporov usmerjena $\mathrm{v}$ tisto, kar prispevamo $\mathrm{v}$ zavezništvo. To pomeni, da kadar v načrtovane zmogljivosti dajemo premalo virov, izpade, kot da vse gradimo le za zavezništvo, v bistvu pa izpolnjujemo le najnujnejši del ciljev za oblikovanje zmogljivosti. Zato verjamem, da obstajajo tudi mnenja, po katerih bi vojaške strukture preoblikovali tako, da bi za vojaško osebje namenjali manj sredstev in preostanek preusmerili $\mathrm{v}$ tehnološko ter drugo opremo oziroma $\mathrm{v}$ investicije v obrambno-vojaškem sistemu. Čeprav gre za prepoznavno paradigmo, ki jo srečamo v številnih primerih v gospodarstvu, je treba izpostaviti, da se ta praksa $\mathrm{v}$ javni upravi v Sloveniji ni potrdila.

Sklep Zaradi dinamike preteklih sprememb ima Slovenska vojska razvojno hipoteko, ki je ni mogoče skriti in zanikati. Tisti, ki smo bodisi na političnem bodisi na vojaškostrokovnem parketu pri tem sodelovali, se pečata za omenjeno hipoteko ne moremo znebiti. V prihodnje bi se lahko znebili ponavljanja napak ali primerov slabih praks. Morali bi izboljšati vizijo za spremembe in njihovo uresničitev. Morali bi tudi vzpostaviti predvsem družbeni in še posebej politični konsenz o tem, kaj hočemo, zmoremo in lahko dosežemo na obrambno-vojaškem področju. Kot kaže, je vizija za transformacijo vojske, to je na znanju temelječa in premišljena preobrazba, v slovenskem primeru pahnjena na obrobje, čeprav je še vedno zapisana v strateških dokumentih. Tudi zato mi naj tisti, ki se s pojmom in pojavom transformacije ne strinjajo preveč, oprostijo njeno izpostavljanje. Iz revolucij, reformacij in kar je še temeljitih pojavov sprememb vemo, da so bile pospremljene s protirevolucijami ali protireformacijami. Upamo lahko, da sedanja razvojna praksa naše vojske ni protitransformacijska. Ta namreč vodi v dokončno pogubo, če uporabim nekoliko bolj literarni izraz. 
Čeprav je slovenski obrambno-vojaški sistem na sredini poti glede spremembe normativnih rešitev, strateškega načrtovanja in opisanega pripravljanja sprememb strukture in obsega vojske, menim, da potrebujemo drugačno vizijo, zato pa politični konsenz in preudaren pristop $\mathrm{k}$ spremembam. Čeprav se sliši heretično, mora iti obrambno planiranje na začetek te poti. Ne zato, da bi ponovno analizirali stanje, temveč zato, da bi preverili ustreznost rešitev. Politika mora nato opraviti svoj del pristojnosti in odgovornosti, povezanih z odločitvami, o katerih sem pisal (če ne prej, po parlamentarnih volitvah). Kakršna koli zamisel, da bomo na hitro ali v kratkem času vse spremenili, bo prej v škodo kot v prednost dobrim rešitvam. Tisto, s čimer bi morali takoj začeti, je konsolidacija vojske z ukrepi za zaustavitev negativnih trendov predvsem v ključnih strukturnih elementih pri profesionalizaciji vojske in eroziji njenih vojaških zmogljivosti.

\section{Literatura}

1. DZ RS, 2016. Zahteva za sklic nujne seje odbora za obrambo-gradiva za sejo. http://imss.dz-rs.si/imis/f32f64faf59434187842.pdf, 2. 11. 1017.

2. GŠSV, 2017a. Prihodnost Slovenske vojske-izhodišča za razpravo na posvetu 28. 3. 2017.

3. GŠSV, 2017b. Povzetek posveta o prihodnosti Slovenske vojske, št. 800-1/2017-25, z dne 21. 4. 2017.

4. GŠSV, 2017c. Povzetek strokovnega posveta o bodoči organizaciji in obsegu Slovenske vojske, št. 800-1/2017-27, z dne 22. 5. 2017.

5. Katičeva razočarana nad obravnavo obrambne zakonodaje. Delo - spletni portal 27. 7. 2017. http://www.delo.si/novice/politika/katiceva-si-na-seji-vlade-zeli-obravnavoobrambne-zakonodaje.html, 2. 11. 1017.

6. Kotnik Igor. 2015. Profesionalizacija Slovenske vojske - cilj ali pot. Sodobni vojaški izzivi, 17 št. 4, str. 11-25.

7. MO RS, 2012. Doktrina vojaške strateške rezerve Republike Slovenije. http://dk.mors.si/IzpisGradiva.php?id=524 (2. 11. 2017).

8. MO RS, 2017a. Novinarska konferenca Ministrstvo za obrambo, 13. marec 2017 gradivo za medije. http://www.mo.gov.si/fileadmin/mo.gov.si/pageuploads/pdf/javne objave/2017/Novinarska_MORS_gradivo170313.pdf, 2. 11. 2017.

9. MO RS, 2017b. Vlada sprejela predlog Zakona o obrambi. http://www.mo.gov.si/si/ medijsko_sredisce/novica/article/1328/8101/, 2. 11. 2017.

10. Novi zakon o obrambi odvisen od sindikatov. Dnevnik-spletni portal, 13. 5. 2016, http://www.mo.gov.si/si/medijsko_sredisce/novica/article/1328/8101/, 2. 17. 2017.

11. Pismo dr. Miro Cerar, predsednik Vlade Republike Slovenije, podpisniki upokojeni generali in brigadirji Slovenske vojske. 29. 8. 2017, hrani avtor.

12. Predlog Sprememb in dopolnitev Srednjeročnega obrambnega programa Republike Slovenije 2016-2020. http://84.39.218.201/MANDAT14/VLADNAGRADIVA.NSF/18 a6b9887c33a0bdc12570e50034eb54/f060e4d9db7fc151c125815b00471e34/\$FILE/ SpremSOPR.pdf, 2. 11. 2017.

13. ReSDPRO SV 2025 - Resolucija o splošnem dolgoročnem programu razvoja in opremljanja Slovenske vojske do leta 2025. http://www.mo.gov.si/fileadmin/mo.gov.si/ pageuploads/pdf/ministrstvo/ReDPROSV25_slo_en.pdf, 2. 11. 2017.

14. SOPR - Srednjeročni obrambni program Republike Slovenije, VRS, št. 80300-2/2016/3, z dne 17. 2. 2016. 
15. SPO - Strateški pregled obrambe 2016. http://www.mo.gov.si/fileadmin/mo.gov.si/ pageuploads/pdf/javne_objave/2017/SPO2016_slo.pdf, 2.11.2017

16. SPOR 2009 - Strateški pregled obrambnega resorja - Povzetek ključnih ugotovitev SPOR 2009 - za komuniciranje z zainteresiranimi javnostmi http://www.mo.gov.si/fileadmin/ mo.gov.si/pageuploads/pdf/ministrstvo/SPOR2009.pdf, 2. 11. 2017.

17. Šteiner, Alojz ur., 2016. Vloga rezerve pri zagotavljanju vzdržljivosti obrambno-varnostnih sistemov Slovenije - Zbornik. Ljubljana: Državni svet.

18. Šteiner, Alojz, 2015. Slovenska vojska med tranzicijo in transformacijo. Ljubljana: Collegium graphicum.

19. UKOM - Urad vlade RS za komuniciranje, 2017. 145. seja vlade RS-Sporočilo za javnost VRS, z dne 27. 7. 2017. http://www.vlada.si/fileadmin/dokumenti/si/Sporocila_za_ javnost/2017/07/sevl145.pdf, 2. 11. 2017.

20. VRS, 2016. Sklepi strateškega pregleda obrambe 2016. Sklep VRS, št. 80400-1/2016/6, z dne 22. 12. 2016.

21. VRS, 2017. Sklep VRS, št. 80400-1/2016/11, z dne 11. 5. 2017.

22. Young, Thomas-Durell, 2016. Izziv za obrambne reforme v srednji/vzhodni Evropi: primer Slovenije. Sodobni vojaški izzivi, 18, št. 4, str. 15-34.

23. Zakon o obrambi, Predlog EVA 2016-1911-0001, z dne 1. 9. 2017. http://www.mo.gov.si/ fileadmin/mo.gov.si/pageuploads/pdf/predpisi/obramba/v_pripravi/ZObr31092017.docx, 2. 11.1017 .

24. Zakon o službi v Slovenski vojski (ZSSloV), Predlog EVA 2011-1911-0001, z dne 1. 9. 2017. http://www.mo.gov.si/fileadmin/mo.gov.si/pageuploads/pdf/predpisi/obramba/v pripravi/ZSSloV31092017.doc, 2. 11. 2017.

25. Žurga, Vida, 2016. Nova sodobna grožnja nacionalni varnosti - proračunska grožnja. Sodobni vojaški izzivi, 18, št. 4, str. 35-50. 